\title{
UPAYA MITIGASI RISIKO PEMBIAYAAN PADA KSPPS BMT AMANAH UMMAH SURABAYA ${ }^{1}$
}

\author{
Elicha Pusparini \\ Departemen Ekonomi Syariah - Fakultas Ekonomi dan Bisnis - Universitas Airlangga \\ Email: elicha.pusparini-2014@feb.unair.ac.id \\ Muhammad Nafik H.R \\ Departemen Ekonomi Syariah - Fakultas Ekonomi dan Bisnis - Universitas Airlangga \\ Email: muhammadnafik@feb.unair.ac.id
}

\begin{abstract}
:
Sharia Cooperation as a micro financial institution does its function to collect and distribute money. Sharia cooperation, as how it works, is initiated by its members, for the members, and from the members. Therefore, the fund channeling done by sharia cooperation is only focusing to the members' welfare. On doing the business, BMT utilizes Sharia contracts such as mudharabah, musyarakah, murabahah, and many more. BMT which was established based on cooperation basic law, must follow the provisions from Ministry of Cooperation in carrying out the business activities. This study uses a qualitative approach with a case study method. The results of this study are risk control measures in murabahah financing contained in the Standard Operating Procedure (SOP). The form of risk control is directed at risk mitigation actions, if risk mitigation is less accurate it will lead to problematic financing. To reduce the number of problematic financing is carried out with preventive measures when submitting, analyzing, realizing and paying off. By focusing on these stages, the possibility of a risk can be minimized.
\end{abstract}

Keywords: Risk, Financing Risk, Murabahah Agreement, Sharia Cooperative, BMT

\section{PENDAHULUAN}

Seiring dengan berkembangan

Ekonomi Islam, masyarakat mulai sadar akan pentingnya membangun sistem ekonomi yang islami. Al-Quran dan Hadits sebagai tuntunan yang telah diberikan Allah SWT dalam menjalankan fungsi kehidupan sebagai khalifah di Bumi. Perkembangan siistem keuangan syariah ini masih berjalan hingga saat ini. Dengan diawali oleh berdirinya Bank Muamalat Indonesia sebagai bank syariah pertama, hingga kemudian mulai bermunculan lembaga keuangan syariah lainnya seperti, BPRS (Bank Pembiayaan Rakyat Syariah), BMT
(Baitul Mal wa Tamwil), takaful dan lain sebagainya.

Koperasi merupakan lembaga yang tidak dapat dilepaskan dari proses pembangunan Indonesia. Dari sejarah awal pada tahun 1927 dibentuklah Serikat Dagang Islam. Dengan tujuan untuk memperjuangkan kedudukan ekonomi para pengusaha-pengusaha pribumi. Setelah bangsa Indonesia merdeka tanggal 12 Juli 1947, gerakan koperasi di Indonesia mengadakan Kongres Koperasi pertama kalinya di Tasikmalaya yang kemudian ditetapkanlah sebagai Hari Koperasi Indonesia.

\footnotetext{
${ }^{1}$ Jurnal ini merupakan bagian dari skripsi dari Elicha Pusparini, NIM : 041411431058 diuji pada 25 Juni 2019.
} 
Koperasi syariah pertama kali dalam bentuk paguyuban bernama Syarikat dagang Islam (SDI) didirikan oleh H. Samanhudi di Solo, Jawa tengah yang beranggotakan pedagang muslim. Koperasi syariah mulai berkembang ketika Baitul Mal wa Tamwil (BMT) mulai berdiri. BMT pertama kali berdiri adalah BMT Bina Insan Kamil tahun 1992 di Jakarta. Pada awalnya BMT sempat terkendala dengan Undang-undang nomor 7 tahun 1992 tentang perbankan yang menyebutkan segala kegiatan dalam bentuk penghimpunan dana masyarakat baik dalam bentuk tabungan dan penyaluran pembiayaan harus berbentuk bank. Pada awalnya BMT hanya berbentuk KSM (kelompok swadaya masyarakat) berbasis syariah hingga muncul beberapa lembaga pengembangan swadaya masyarakat (LPSM) yang mencoba memayungi KSM BMT. LPSM tersebut awalnya dipelopori oleh P3UK, PINBUK oleh ICMI dan FES dompet Dhuafa oleh republika. Kegiatan ekonomi berbasis kerakyatan yang dianut BMT memiliki nilai yang sama dengan kegiatan koperasi, maka berdasarkan undang-undang RI nomor 25 tahun 1992 BMT dapat menggunakan badan hukum koperasi.

Dalam setiap kegiatan pembiayaan yang dilakukan tidak akan lepas dari risiko. Oleh karena itu, perlu dilakukan tindakan pencegahan sebelum terjadinya risiko yang nantinya dapat menimbulkan kerugian bagi perusahaan. Menurut Kusmiyati (2007) risiko yang dapat dialami oleh BMT diantaranya, penyalahgunaan dana oleh anggota, penundaan pembayaran dan pembatalan akad oleh anggota. Risiko tersebut dapat terjadi ketika upaya pencegahan yang dilakukan masih belum memadai. Menurut Fikruddin (2015) manajemen risiko yang telah dilakukan dapat dilihat dari SOP yang dijalankan secara efektif dan dapat ditangani dengan baik.

Menurut Romdhoni (2016) dalam menyalurkan pembiayaan BMT perlu memiliki prosedur yang dapat memperkecil risiko kerugian mulai dari awal pengajuan, proses terjadinya akad hingga realisasi dana. Dengan adanya prosedur yang kemudian dilaksanakan oleh karyawan secara teratur maka akan mampu meminimalisir risiko.

Dari serangkaian prosedur manajemen risiko yang digunakan untuk mengidentifikasi, mengukur, memantau dan mengendalikan risiko yang timbul dari kegiatan pembiayaan. Kemungkinan terjadinya risiko pada proses pembiayaan tentu menjadi hal yang kurang menguntungkan perusahaan. Berdasarkan penjelasan diatas maka judul penelitian ini akan berfokus pada bagaimana upaya yang dilakukan oleh KSPPS BMT Amanah Ummah Surabaya dalam mengendalikan terjadinya risiko pembiayaan murabahah.Sesuai 
Pusparini, et al/Jurnal Ekonomi Syariah Teori dan Terapan Vol. 6 No. 8 Agustus 2019: 1578-1593; UPAYA MITIGASI RISIKO PEMBIAYAAN PADA KSPPS BMT AMANAH UMMAH SURABAYA

dengan rumusan masalah diatas, tujuan dari dilakukannya penelitian ini untuk mengetahui upaya apa saja yang dilakukan oleh KSPPS BMT Amanah Ummah dalam menjalankan prinsip kehati-hatian dalam proses pembiayaan produktif yang disalurkan kepada usaha kecil dan mikro untuk meminimalisir terjadinya risiko yang dapat menimbulkan kerugian dimasa yang datang.

\section{LANDASAN TEORI DAN PENGEMBANGAN HIPOTESIS}

\section{Baitul Mal wa Tamwil (BMT)}

Baitul Maal wa Tamwil (BMT) merupakan salah satu lembaga keuangan mikro yang dioperasikan dengan prinsip-prinsip syariah Islam yang tata cara beroperasinya mengacu kepada ketentuanketentuan Al-Qur'an dan Hadist. Baitul Maal wa Tamwil (BMT) beroperasi mengikuti ketentuan-ketentuan syari'ah Islam khususnya yang menyangkut tata cara bermuamalah secara Islam. Dalam tata cara bermuamalah itu menghindari praktek-praktek yang mengandung unsur-unsur riba sehingga lebih diarahkan pada kegiatan-kegiatan investasi atas dasar bagi hasil dan pembiayaan perdagangan. Dalam kamus kontemporer Arab-Indonesia, baitul maal diartikan sebagai rumah dana/harta dan baitul tamwil diartikan sebagai rumah usaha atau rumah pembiayaan. Baitul maal dikembangkan berdasarkan sejarah perkembangan Islam. Dimana baitul maal dikembangkan untuk mengumpulkan sekaligus mentasyarufkan dana sosial. Sedangkan baitul tamwil merupakan lembaga bisnis yang bertjuan untuk memperoleh profit.

Istilah Baitul Maal wa Tamwil berasal dari dua kata, yaitu Baitul Maal dan Baitul Tamwil. Istilah Baitul Maal berasal dari kata bait dan al mal. Kata bait yang bearti rumah atau bangunan, sedangkan al mal berarti harta benda atau kekayaan. Namun kata Baitul Maal dapat diartikan sebagai perbendaharaan baik secara umum maupun Negara. Sedangkan Baitul Tamwil berarti rumah penyimpanan harta milik pribadi yang dikelola dan dimanfaatkan oleh suatu lembaga keuangan guna menambah nilai tambah atas suatu kegiatan usaha lebih lanjut (Harun Nasution, 1992:161) dalam (Lubis dan Farid, 2012:124) Baitul Maal wa Tamwil (BMT) terdiri dari dua istilah, yaitu baitul maal dan baitul tamwil. Baitul maal lebih mengarah pada usaha-usaha pengumpulan dan penyaluran dana yang non profit, seperti zakat, infak dan shodaqoh. Sedangkan baitut tamwil sebagai usaha pengumpulan dan dan penyaluran dana komersial (Prof. H A. Djazuli: 2002). 


\section{Pembiayaan}

Istilah pembiayaan memiliki arti kepercayaan (trust) dalam hal ini lembaga pembiayaan selaku shahibul mal menaruh kepercayaan kepada seseorang yang ditinjuk sebagai mudharib untuk melaksanakan amanah yang diberikan. Dana tersebutharus digunakan dengan benar, adil dan disertai dengan ikatan dan syarat-syarat yang jelas, dan menguntungkan kedua belah pihak, seperti yang difirmankan oleh Allah SWT dalam surat Al-Nisa [4]: 29

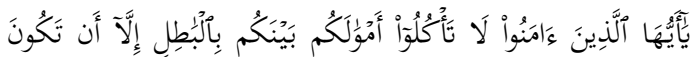

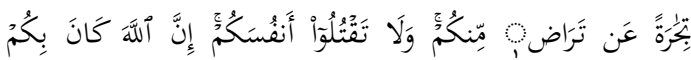

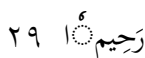

Artinya: Hai orang-orang yang beriman, janganlah kamu saling memakan harta sesamamu dengan jalan yang batil, kecuali dengan jalan perniagaan yang berlaku dengan suka sama-suka di antara kamu. Dan janganlah kamu membunuh dirimu; sesungguhnya Allah adalah Maha Penyayang kepadamu.

\section{Murabahah}

Murabahah merupakan salah satu akad yang biasa digunakan dalam jual beli dengan menyatakan harga perolehan dan margin (keuntungan) yang telah disepakati pihak penjual dan pembeli. Harga yang telah disepakati dalam akad murabahah adalah harga jual sedangkan harga beli dari barang tersebut harus diberitahukan. Pembayaran murabahah dapat dilakuakn secara tunai atau cicilan. Dalam akad murabahah, bank juga dapat meminta agunan sebagai jaminan atas akad murabahah (Muhamad, 2016)

Rivai dan Andria

(2008) Murabahah merupakan akad jual beli barang, dengan harga yang disepakati kedua pihak antara penjual dan pembeli, dimana penjual terlebih dahulu menyebutkan harga perolehan sebelumnya atas suatu barang serta menyebutkan besarnya keuntungan yang diperolehnya. Landasan hokum Murabahah

Surah Al-Baqarah [2]:275

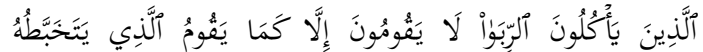

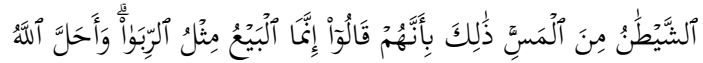

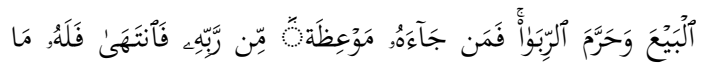

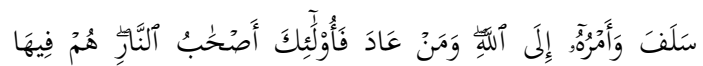

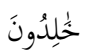

Artinya: Orang-orang yang makan (mengambil) riba tidak dapat berdiri melainkan seperti berdirinya orang yang kemasukan syaitan lantaran (tekanan) penyakit gila. Keadaan mereka yang demikian itu, adalah disebabkan mereka berkata (berpendapat), sesungguhnya jual beli itu sama dengan riba, padahal Allah telah menghalalkan jual beli dan mengharamkan riba. Orang-orang yang telah sampai kepadanya larangan dari Tuhannya, lalu terus berhenti (dari mengambil riba), maka baginya apa yang telah diambilnya dahulu (sebelum datang 
larangan); dan urusannya (terserah) kepada Allah. Orang yang kembali (mengambil riba), maka orang itu adalah penghuni-penghuni neraka; mereka kekal di dalamnya. [Al Baqarah:275]

\section{Manajemen Risiko}

Risiko merupakan ketidakpastian atau kemungkinan terjadinya sesuatu, yang bila terjadi akan menimbulkan kerugian (Djojosoedarso, 1999). Risiko selalu dihubungkan dengan kemungkinan terjadinya sesuatu yang merugikan dan terjadi secara tak terduga, karakteristik risiko dapat didefinisikan dengan sebuah ketidakpastian atas terjadinya suatu peristiwa dan ketidakpastian yang menimbulkan kerugian.

Menurut sumber/penyebab timbulnya risiko dapat dibedakan menjadi dua, yaitu; (1) risiko intern dan risiko ekstern. Risiko intern merupaka risiko yang berasal dari dalam perusahaan, seperti kerugian aktiva akbiat kelalaian karyawan, kecelakaan kerja, mismanajemen dan lain sebagainya. Untuk risiko ekstern merupakan risiko yang muncul diluar perusahaan, seperti risiko pencurian, penipuan, persaingan, fluktuasi harga, perubahan peraturan pemerintah dan sebagainya (Djojosoedarjo, 1999).

Risiko timbul karena suatu ketidakpastian, ketidakpastian merupakan kondisi yang menyebabkan timbulnya risiko. Dengan adanya ketidakpastian akan menimbulkan keragu-raguan mengenai hasil-hasil yang kana terjadi kedepannya. Menurut Djojosoedarjo (1999), ketidakpastian dapat diklasifikasikan menjadi:

1. Ketidakpastian ekonomi, yaitu kejadian-kejadian yang timbul akibat kondisi dan pelaku ekonomi, misalnya: perubahan sikap konsumen, perubahan selera konsumen, perubahan harga, perubahan teknologi, penemuan baru dan sebagainya.

2. Ketidakpastian alam, yaitu ketidakpastian yang disebabkan oleh alam, misalnya: badai, banjir, kebakaran dan sebagainya.

3. Ketidakpastian kemanusiaan, yaitu ketidakpastian yang disebabkan oleh perilaku manusia seperti: pencurian, peperangan, penggelapan, pembunuhan dan sebagainya.

Manajemen risiko adalah penanggulangan risiko dapat dilakukan dengan berbagai cara dan pengelolaan berbagai cara penanggunlangan tersebut. Pengelolaan tersebut meliputi:

1. Berusaha untuk mengidentifikasi unsur-unsur ketidak pastian dan tipetipe risiko yang dihadapi bisnisnya.

2. Berusaha untuk menghindari dan menanggulangi semua unsur ketidakpastian, misalnya dengan 
membuat perencanaan yang baik dan cermat.

3. Berusaha untuk mengetahui korelasi dan konsekuensi antar peristiwa, sehingga dapat diketahui risiko-risiko yang terkandung dalamnnya.

4. Berusaha untuk mencari dan mengambil langkah-langkah (metode) untuk menangani risikorisiko yang telah berhasil diidentifikasi (mengelola risiko dihadapi).

\section{Manajemen Risiko Islami}

Oleh karenanya, manajemen risiko sangat penting dilakukan guna mencegah terjadinya kegagalan yang menimbulkan kerugian baik bagi nasabah maupun bank. Lembaga keuangan yang melakukan system operasinya perlu melakuakn manajemen risiko dengan melakukan identifikasi, mengukur, memantau dan mengendalikan risiko yang dapat terjadi (Rustam, 2013). Tertuang dalam Firman Allah dalam Surah Yusuf ayat 55

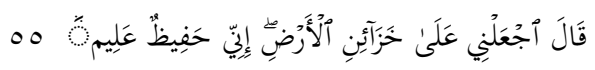

qālaj'alnī 'alā khazāininil-ard, innī ḥafī̦un 'alim

Artinya: Berkata Yusuf: "Jadikanlah aku bendaharawan negara (Mesir); sesungguhnya aku adalah orang yang pandai menjaga, lagi berpengetahuan".

Kemudian ditegaskan kembali dalam Surah Al-Baqarah 283

$$
\begin{aligned}
& \text { 罗 }
\end{aligned}
$$

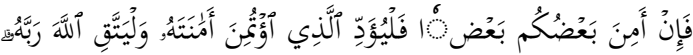

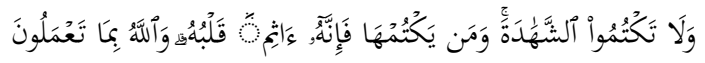
عَلِيَّة Artinya: Jika kamu dalam perjalanan (dan bermu'amalah tidak secara tunai) sedang kamu tidak memperoleh seorang penulis, maka hendaklah ada barang tanggungan yang dipegang (oleh yang berpiutang). Akan tetapi jika sebagian kamu mempercayai sebagian yang lain, maka hendaklah yang dipercayai itu menunaikan amanatnya (hutangnya) dan hendaklah ia bertakwa kepada Allah Tuhannya; dan janganlah kamu (para saksi) menyembunyikan persaksian. Dan barangsiapa yang menyembunyikannya, maka sesungguhnya ia adalah orang yang berdosa hatinya; dan Allah Maha Mengetahui apa yang kamu kerjakan.

\section{Manajemen Risiko Koperasi BMT}

Risk management (manajemen risiko) dalam pengelolaan lembaga keuangan mikro syariah berbentuk BMT dan lembaga sejenidmya adalah suatu prioritas yang mutlka untuk diperhatikan. Manajemen risiko akan menjaga keberlangsungan suatu lembaga BMT untuk terus berjalan melayani anggota. Lembaga BMT yang memiliki aktivitas utama sebagai lembaga intermediary antar anggota dan pengelola sebagai penyalur dana pihak ketiga serta meminimalisir risiko penggunaan dana. Tujuan dikelolanya risiko dengan baik adalah untuk mempertahankan kepercayaan pemangku kepentingan 
Pusparini, et al/Jurnal Ekonomi Syariah Teori dan Terapan Vol. 6 No. 8 Agustus 2019: 1578-1593; UPAYA MITIGASI RISIKO PEMBIAYAAN PADA KSPPS BMT AMANAH UMMAH SURABAYA

dalam melindungi dana anggota (Ajija dkk, 2018).

Pemahaman

tentang

manajemen risiko berangkat dari pengertian dasar tentang risiko dan implementasi dari suatu perencanaan.seiap organisasi akan berhadapan pada kondisi factor internal dan eksternal yang mengganggu keseimbangan kinerja suatu organisasi, yang dapat disebut sebagai risiko positif atau negatif. Dalam konteks manajemen risiko, perencanaan suatu program kerja yang memiliki hasil negatiif adalah identic dengan proses risiko yang perlu dihilangkan dan diminimalisir.

Dalam pengelolaan risiko berdasarkan sumbernya, ada risiko yang berasal dari internal dan eksternal.

Pengelola BMT dan sejenisnya harus mampu untuk mendeteksi dan melakukan pemetaan terhadap berbagai macam risiko agar mampu diminimalisir. Risiko internal adalah adanya kemungkinan terhadap perencanaan bisnis BMT yang berasal dari dalam kelembagaan, sedangkan risiko eksternal adalah berbagai kemungkinan terhadap perencanaan bisnis yang berasal dari luar lembaga/ kedua factor tersebut harus mampu diminimalisir dengan baik oleh BMT di Indonesia.

\section{Manajemen Risiko Pembiayaan}

\section{Murabahah}

Risiko pembiayaan merupakan kemungkinan terjadinya kondisi-kondisi yang tidak teridentifikasi sebelumnya. Dalam praktek pembiayaan tentu tidak dapat terlepas dari risiko pembiayaan. risiko pembiayaan sering disebut dengan default risk yang merupakan risiko yang ditimbulkan dari ketidak mampuan nasabah dalam mengembalikan pembiayaan yang diterima sesuai dengan waktu yang telah ditentukan (Rivai dan Rifki, 2013). Risiko yang dihadapi lembaga kevangan syariah berbeda antara satu dengan yang lain seperti pada pembiayaan Murabahah merupakan pembiayaan jual beli dengan ketentuan nilai harga pokok ditambah dengan margin yang disepakati. Untuk transaksi murabahah yang sifatnya tidak mengikat menyebabkan risikopembatalan transaksi dan penurunan nilai barang akibat cacat atau rusak.

Menurut Antonio (2001) upaya yang dapat diantisipasi pada pembiayaan murabahah adalah kelalaian nasabah tidak membayar angsuran, fluktuasi harga pasar yang dapat mempengaruhi harga jual-beli, barang yang telah dibelikan tidak sesuai sehingga terjadi penolakan oleh nasabah, dan nasabah menjual barang karena dalam pembiayaan murabahab 
Pusparini, et al/Jurnal Ekonomi Syariah Teori dan Terapan Vol. 6 No. 8 Agustus 2019: 1578-1593; UPAYA MITIGASI RISIKO PEMBIAYAAN PADA KSPPS BMT AMANAH UMMAH SURABAYA

bersifat jual-beli sehingga barang telah menjadi milik nasabah.

\section{METODE PENELITIAN}

Jenis penelitian ini adalah deskriptif analisis, yaitu penulis akan menggambarkan permasalahn dengan didasari data-data yang ada lalu di analisis lebih lanjut sehingga dapat diambil kesimpulan dari penelitian ini. Menurut Yin (2015:2) pendekatan kualitatif adalah pendekatan dengan menggunakan data dalam bentuk kalimat deskriptif tertulis atau lisan, peristiwa, pengetahuan, atau proyek studi.

Menurut Taylor dan Bogdan dalam buku suyanto dan Sutinah (2008:166) Penelitian kualitatif dapat diartikan sebagai penelitian yang menghasilkan data deskriptif tentang kata-kata lisan maupun tertulis, dan tingkah laku yang dapat diamati dari orang-orang yang diteliti. Penelitian ini menggunakan penelitian kualitatif karena untuk menjawab rumusan masalah secara lengkap dan mendalam mengenai upaya pengendalian risiko yang terjadi pada pembiayaan Murabaha pada KSPPS BMT Amanah Ummah Jawa Timur.

Metode pengumpulan data yaitu dengan:

\section{Wawancara}

Penelitian ini menggunakan wawancara di mana peneliti telah menyiapkan daftar pertanyaan mengenai topic yang akan diteliti.
Wawancara akan ditujukan kepada pengurus serta pengelola KSPPS BMT Amanah Ummah. pemilihan pengurus sebagai informan kunci dalam penelitian ini karena sebagai pihak yang mengerti pelaksanaan operasi pembiayaan. Kemudian pengelola sebagai pihak yang menangani secara langsung anggota yang melakukan pembiayaan. Wawancara dilakukan untuk menggali segala informasi serta untuk mendapatkan gambaran secara menyeluruh pada penelittian ini.

2. Observasi

Observasi bisa dilakukan selama dilakukan kunjungan lapangan termasuk kesempatan-kesempatan selama pengumpulan bukti selain pada wawancara. Pada penelitian ini, observasi bertujuan untuk mengamati proses pembiayaan dari awal pengajuan sampai pelunasan pembiayaan, sehingga dapat diketahui bagaimana proses pengendalian risiko pembiayaan pada KSPPS BMT Amanah Ummah.

3. Dokumentasi

Dokumen dipilih sebagai penguat data-data yang ditemukan ketika di lapangan sehingga data yang ditemukan agar lebih kuat argument dan pembuktiannya. Menurut Yin (2015) jenis dokumen yaitu: memorandum, kesimpulan pertemuan, laporan peristiwa tertulis, 
dokumen administrasi, penelitian terdahulu, kliping dan artikel baru. Dokumen juga menjadi tambahan rician spesifik guna mendukung informasi dari sumber lain.

\section{Teknik Keabsahan Data}

Dalam metodologi kualitatif ada empat kriteria yang berhubungan dengan keabsahan data yaitu triangulasi data, triangulasi pengamat, triangulasi teori, triangulasi metode. Penelitian ini akan menggunakan teknik keabsahan sebagai berikut (Afifudin dan Saebani, 2012:143):

1. Triangulasi data

Menggunakan berbagai sumber data dengan cara menggali sumber dan mengecek derajat kepercayaan suatu data yang telah diperoleh melalui berbagai sumber seperti, dokumen, arsip, hasil wawancara, hasil observasi atau wawancara lebih dari satu subyek yang dianggap memiliki sudut pandang berbeda. Metode ini akan membandingkan keselarasan wawancara antara pihak pengurus dan pengelola KSPPS BMT Amanah Ummah.

2. Triangulasi metode

Metode ini dilakukan dengan membandingkan informasi atau data dengan cara berbeda. Untuk memperoleh kebenaran informasi dan gambaran yang utuh mengenai informasi tertentu, peneliti bisa menggunakan metode wawancara bebas dan terstruktur atau peneliti menggunakan metode wawancara dan observasi untuk mengecek kebenaran. Pada penelitian ini akan menyesuaikan antara wawancara, observasi di lapangan dan bukti berupa arsip sehingga kebenaran data yang diperoleh lebih akurat.

\section{Teknik Analisis}

Data yang diperoleh dari proses wawancara dan dokumentasi akan dianalisis untuk memperoleh hasil. Setelah hasil analisis data tersebut kemudian dilandaskan pada teori dalam penelitian ini. Dalam penelitian ini menggunakan teknik analisa penjodohan pola. Menurut Yin (2015:140) logika penjododhan pola merupakan membandingkan pola yang didasarkan dengan pola yang diprediksikan. Penelitian studi kasus dengan metode deskriptif akan relevan dengan pola-pola spesifik yang diprediksi dan ditentukan sebelum pengumpulan data.

Dari proses analisis data akan diolah kembali, kemudian akan dihubungkan dan dibandingkan agar dapat diketahui bagaimana mitigasi risiko mengenai pembiayaan murabahah pada KSPPS BMT Amanah Ummah, mulai dari tahap pengajuan, tahap keputusan dan setelah pembiayaan agar dapat diketahui terjadinya risiko pembiayaan supaya dapat ditekan seminimal mungkin.

\section{Hasil dan Pembahasan}

Pengendalian Risiko Pembiayaan 


Risiko pembiayaan adalah
kerugian yang dapat terjadi
dikarenakan anggota tidak mampu
untuk mengembalikan pinjaman yang
diberikan oleh BMT. Hal ini dapat
menyebabkan pembiayaan
bermasalah yang dimana bila pinjaman
tersebut tidak dapat dikembalikan
maka akan mempengaruhi
pendapatan. Dengan kerugian finansial yang disebabkan karena kegagalan debitur dalam membayar kembali pembiayaan yang telah diperoleh. Proses manajemen risiko yang perlu dilakukan yaitu dengan mengidentifikasi, mengukur, monitoring, mengontrol risiko pembiayaan.

Kebijakan pembiayaan yang dilakukan harus mencakup; prinsip kehati-hatian, kebijakan persetujuan, dokumentasi administrasi, pengawasan pembiayaan dan penyelesaian pembiayaan bermasalah (Rivai dan Andria, 2008). Dari kebijakan tersebut, diperinci kembali mengenai setiap aspek kebijakan. Dengan ini, setiap karyawan baik pengurus maupun pengelola koperasi syariah untuk menjalankan setiap kebijakan yang dibuat agar terhindar dari kemungkinan terjadinya kesalahan. Standart operasi yang dibentuk akan menjadi pedoman setiap karyawan dalam menjalankan tugasnya.

Hal ini tentunya tidak dapat dihindari namun bisa diminimalisir dampaknya. Upaya minimalisir dapat dilakuakn dengan mitigasi risiko pembiayaan. Mitigasi yang dapat dilakukan dalam lima tahap, yaitu tahap pertama mengetahui profil nasabah ketika mengajukan pembiayaan, kedua mengetahui proses pengajuan dengan melakukan survey usaha nasabah, ketiga menentukan kemampuan nasabah dalam mengangsur pembiayaan, keempat monitoring selama pembiayaan dan kelima saat pelunasan.

Bentuk pengendalian pada mitigasi risiko pembiayaan saat pengajuan pada tahap pertama sesuai dengan yang dijelaskan Karim (2010:260) bahwa pada saat proses identifikasi risiko, hal yang perlu diperhatikan adalah karakteristik risiko yang melekat pada aktivitas fungsional dan risiko dari produk dan kegiatan usaha. Yang kedua dilakukan dengan menilai usaha yang sedang dijalankan oleh nasabah. Kegiatan usaha yang diketahui oleh KSPPS BMT Amanah Ummah diidentifikasi kapasitas nasabah. Identifikasi ketiga adalah menilai kemampuan nasabah dalam mengangsur pembiayaan. Hal ini dapat diketahui ketika pihak $A O$ melakukan survey yang menerapkan prinsip 5C, yaitu Character, Collateral, Capital, Capacity, Condition Of Economy. Identifikasi keempat adalah monitoring selama pembiayaan. Aspek ini sangat penting karena sebagai marketing yang bertanggung jawab 
Pusparini, et al/Jurnal Ekonomi Syariah Teori dan Terapan Vol. 6 No. 8 Agustus 2019: 1578-1593; UPAYA MITIGASI RISIKO PEMBIAYAAN PADA KSPPS BMT AMANAH UMMAH SURABAYA

atas nasabah harus mampu menangkap sinyal-sinyal kemungkinan terjadi kerugian pada proses berjalannya pembiayaan.

\section{Pengendalian Risiko Pembiayaan Murabahah}

Proses awal pengajuan yaitu saat nasabah datang pertama kali kepada pihak marketing atau Account Officer (AO). Nasabah akan mengajukan pembiayaan dengan membawa syarat-syarat yang telah ditentukan oleh KSPPS BMT Amanah Ummah. Adapula nasabah yang sudah lama dan mendatangi langsung ke kantor atau juga bisa menghubungi marketing secara langsung. Dari datadata yang diajukan oleh nasabah, oleh marketing akan dilakukan pengecekan atas keabsahan data tersebut. Ketika nasabah pertama kali mengajukan pembiayaan maka dilakukan wawancara mengenai usaha maupun pembiayaan yang dibutuhkan. Pada tahap pengajuan, pihak marketing dituntut untuk memahami akad-akad yang sesuai untuk digunakan dalam pembiayaan supaya tujuan penggunaannya jelas dan tidak menyimpang. Dalam hal ini, KSPPS BMT Amanah Ummah lebih memprioritaskan pembiayaan produktif yang diharapkan dapat membantu meningkatkan perekonomian masyarakat kecil.

Proses selanjutnya yaitu analisa usaha sangat diperlukan untuk menentukan jenis pembiayaan yang akan digunakan. Dilihat dari kemampuan nasabah dalam menjalankan usahanya, pengalaman yang diperoleh nasabah selama menjalankan bisnis akan sangat berpengaruh pada konsistensi usahanya. Pada umumnya lembaga pembiayaan akan enggan memberikan pembiayaan untuk usaha yang masih baru, meskipun tentu masih ada beberapa pertimbangan lain untuk menerima sebuah pembiayaan usaha baru. Informasi mengenai usaha yaitu berupa akta pendirian, namun pada prakteknya di KSPPS BMT Amanah Ummah karena anggota yang merupakan usaha kecil, mikro dan menengah yang masih belum melakukan pengurusan ijin resmi sehingga akta pendirian tersebut bukan menjadi acuan wajib untuk menilai usaha. Penilaian yang dilakukan tidak hanya tentang kapasitas dan modal saja, tapi juga analisis 5C yang dimana juga terdapak aspek kapasitas dan modal. Metode analisis ini sudah umum digunakan baik di perbankan maupuun di lembaga keuangan mikro. Penerapan analisis $5 \mathrm{C}$ penting dilakukan guna memitigasi terjadinya risiko

1. Character

Karakter adalah watak/sifat dari calon anggota dalam kehidupan bermasyarakat maupun lingkungan usaha. Penilaian atas karakter ini untuk mengetahui sejauh mana anggota dalam komitmennya 
menjalankan kewajiban saat pembiayaan. Pada KSPPS BMT Amanah Ummah, kemampuan marketing dalam menganalisis karakter seorang nasabah dilihat dari seberapa besar pengalaman yang dimiliki marketing tersebut Untuk menilai karakter anggota dapat diketahui dari sikap dan moral yang baik, memiliki rasa tanggung jawab. Karakter seorang calon anggota dapat dinilai dari cara berbicara, bagaimana gerak gerik ketika diwawancara. Marketing juga harus untuk memahami berbagai macam karakter orang yang ia temui dilapangan. Semakin tinggi jam terbang seorang marketing maka akan semakin tinggi pengalamannya dalam menilai karakter seseorang. Kemampuan dalam menganalisis karakter seorang nasabah dilihat dari seberapa besar pengalaman yang dimiliki marketing tersebut

2. Capacity

Kapasitas disini menjelaskan mengenai bagaimana kemampuan calon anggota dalam mengembalikan angsurannya tepat waktu. untuk mengetahui seberapa besar kapasitas seorang calon anggota dalam memberikan pelunasan tepat waktu, dapat diketahui dari berapa jumlah keuntungan baik setiap hati maupun setiap bulannya yang dikurangi dengan jumlah pengeluaran wajib.
Marketing dapat menentukan besaran angsuran yang mampu dilakukan oleh calon anggota setelah mengetahui berapa jumlah pendapatan dikurangi jumlah pengeluaran. Jika sisa antara pendapatan dan pengeluaran tidak melebih angsuran, maka pembiayaan tersebut masih bisa dilakukan.

3. Capital

Penilaian atas modal sendiri menjadi penting karena pembiayaan yang dilakukan hanya bersifat tambahan atas modal usaha yang telah dijalankan sebelumnya. Dari modal tersebut, dapat menjadi pertimbangan dalam menilai keseriusan dalam menjalankan usaha, karena secara tidak langsung calon anggota dan koperasi samasama berbagi risiko jika terjadi kerugian.

Pada KSPPS BMT Amanah Ummah, untuk menilai modal dari calon anggota, marketing dapat menilai dari jumlah persediaan barang. Hal ini karena mayoritas usaha yang dibiayai KSPPS BMT Amanah Ummah adalah usaha mikro dan kecil sehingga kebanyakan dari mereka tidak memiliki laporan kevangan khusus sehingga untuk data detail mengenai modal atau keuntungan yang diperoleh harus dilakukan perhitungan manual. Marketing melakukan survey usaha dengan 
memberikan pertanyaan mengenai modal ataupun cash flow per harinya dari calon anggota. Dari data survey tersebut akan dianalisis hingga menghasilkan besaran modal yang dimiliki oleh seorang calon anggota.

4. Collateral

Jaminan menjadi salah satu prinsip penilaian $5 \mathrm{C}$ yang harus diterapkan.

Setiap calon anggota pembiayaan yang permohonan pembiayaan diterima, perlu melakukan penyerahan barang jaminan. Dari nilai wajar atas jaminan akan menjadi pedoman untuk mengukur seberapa besar pemberian pembiayaan yang mampu untuk diberikan. Selain itu, jaminan juga untuk menilai apakah nilai wajar jaminan tersebut dapat mencukupi dari pembiayaan yang diajukan.

Setiap lembaga keuangan memiliki patokan nilai dari sebuah jaminan. Nilai jaminan harus melebihi dari pembiayaan yang disetujui. Hal ini penting sebagai penerapan prinsip kehati-hatian terhadap kemungkinan terjadinya pembiayaan bermasalah. Pada KSPPS BMT Amanah Ummah penerapan limit plafond pembiayaan sebesar maksimal $70 \%$ didasarkan pada jaminan yang dugunakan.

5. Condition of Economy

Kondisi ekonomi adalah kondisi ekonomi secara makro yang dapat mempengaruhi usaha. Misalnya, krisis moneter, meningkatnya suku bunga, terjadi inflasi yang tinggi. Pada prakteknya, perubahan kondisi ekonomi saat ini tidak berpengaruh besar pada usaha meskipun terjadi fluktuasi harga di pasar tetapi masih bisa dikendalikan.

Proses analisis yang dilakukan oleh marketing yang mencakup analisis kualitatif dan kuantitatif. Saat pembiayaan baru diajukan ketika rapat komite akan dilakukan analisa kembali saat marketing menjabarkan hasil survey dan analisa. Setelah marketing menjabarkan hasil analisis, komite akan menilai seberapa besar kemampuan anggota dilihat dari karakter, kemampuan dan jaminan. Penyampaian hasil analisa oleh marketing kepada komite pembiayaan akan menunjukkan kondisi nasabah yang layak atau tidak. Hal ini untuk menghindari kemungkinan terjadinya risiko seperti gagal bayar. Keputusan diterima atau tidaknya sebuah pembiayaan akan diputuskan ketika rapat anggota. Untuk pembiayaan yang diterima, langkaj selanjutnya adalah realisasi yang dilakukan oleh marketing kemudian menyerahkan dana pembiayaan.

Bentuk pengawasan yang dilakukan marketing dengan memantau kelancaran pembiayaan, jika terjadi tunggakan angsuran maka marketing akan menghubungi anggota. 
Selain menghubungi via telepon, marketing juga bisa dating untuk berkunjung ke tempat usaha anggota. Upaya lain yang dapat dilakukan untuk memonitoring anggota adalah dilakukan monitoring atas tabungan. Karena setiap orang atau nasabah yang mengajukan pembiayaan dan diterima di KSPPS BMT Amanah Ummah harus menjadi anggota terlebih dahulu, sehingga anggota memiliki rekening tabungan pada BMT.

Pembiayaan bermasalah tentu tidak akan lepas dari risiko pembiayaan. Pembiayaan yang sudah digolongkan macet atau bermasalah masih bisa untuk diselamatkan dengan cara rescheduling, restructuring danrecondition. Namun, hal ini juga perlu memperhatikan kondisi nasabah. Jika nasabah tersebut masih mampu melakukan angsuran maka metode penyelamatan tersebut dapat dilakukan. Tetapi jika kondisi anggota tidak memungkinkan seperti usahanya yang kolaps atau anggota sakit kronis atau meninggal maka tindakan yang dapat dilakukan adalah penjualan barang jaminan.

\section{v. SIMPULAN}

Dari hasil penelitian yang dilakukan pada KSPPS BMT Amanah Ummah menunjukkan bahwa penerapan manajemen risiko pembiayaan murabahah telah dilakukan sejak awal pengajuan hingga pelunasan. Proses tersebut dilakukan oleh pihak marketing sebagai pihak yang bertanggung jawab atas pembiayaan yang ia lakukan. Dimulai pada tahap pengajuan pembiayaan yang kemudian dilakukan analisis pembiayaan yang melibatkan komite pembiayaan hingga pada keputusan diterima atau ditolaknya sebuah pembiayaan. Setelah melalui proses tersebut maka akan terjadi akad pembiayaan. Setelah itu dilakukan pengawasan atas pembiayaan yang disalurkan. Selama proses pengawasan ini marketing akan aktif memantau anggota sehingga jika terjadi pembiayaan bermasalah akan dapat dilakukan tindakan segera. Bila terjadi pembiayaan bermasalah, marketing dapat melakukan tindakan pencegahan berupa restructuring, recondition, dan rescheduling.

Dalam meminimalisir risiko dapat dilakukan dengan tindakan preventif maupun saat terjadi risiko. Tindakan preventif dilakukan dengan analisis 5C. Dari analisis 5C yang dilakukan oleh marketing untuk menilai kemampuan anggota dalam menyelesaikan pembiayaan hingga akhir. Pada KSPPS BMT Amanah Ummah analisis 5C lebih ditekankan pada penilaian karakter anggota, kondisi usaha dan jaminan. Penilaian karakter dilakukan ketika wawancara dengan yang bersangkutan hingga meminta pendapat dari orang sekitarnya. Kemudian kondisi usaha yaitu BMT 
hanya menerima pembiayaan modal usaha yang telah berjalan lebih dari satu tahun. Penilaian jaminan menjadi aspek yang menjadi perhitungan ketika analisa pembiayaan karena selain untuk menilai kemampuan anggota tetapi juga sebagai bentuk ikatan antara anggota dan BMT jika terjadi wanprestasi oleh anggota.

Dalam hal ini, KSPPS BMT Amanah Ummah telah menerapkan SOP yang ada. Namun, pada analisis pembiayaan perlu ditingkatkan kembali agar supaya analisis yang dilakukan dapat meminimalisir risiko. Peningkatan SDM marketing juga perlu untuk dilakukan pelatihan agar pembiayaan yang disalurkan dapat sesuai dengan ketentuan syariah.

\section{DAFTAR PUSTAKA}

Afifudin dan Beni Ahmad Saebani. 2012. Metodelogi Penelitian Kualitatif. Bandung: Pustaka Setia

Ahmadiono. 2014. Mengendalikan Risiko Lembaga Kevangan Mikro Syariah. Jember: AlMashraf, Vol.1, No. 01 Oktober

Ajija, S. Rohmatul, dkk. 2018. Koperasi BMT Teori, Aplikasi dan Inovasi. Karanganyar. CV. Inti Media Komunika

Al-Hasan, Fahadil Amin. 2018. Analisis pelaksanaan Akad Murabahah di Lembaga Kevangan Syariah (BMT)
Antonio. M. Syafii. 2001. Bank Syariah dari Teori ke Praktek. Jakarta: Gema Insani Press

Djojosoedarso, Soeisno. 1999. Prinsipprinsip manajemne risiko dan asuransi. Jakarta. Salemba Empat

Bi.go.id diakses pada 18 November 2018 pukul 20.22 Tentang UndangUndang Nomor 20Tahun 2008

Cokrohadisumarto, Widiyanto bin Mislan, dkk.2016. BMT: Praktik dan kasus. Jakarta. Rajawali Pers.

Fikruddin, Tahta. 2015. Strategi Penanganan Risiko Pembiayaan Murabahah pada BMT SeKabupaten Demak. Kudus. Equilibrium 3(2) 254-270

Hendrojogi. 2004. Koperasi Asas-Asas, Teori dan Praktik. Jakarta: PT. RajaGrafindo Persada

Karim, Adiwarman Azwar. 2010. Bank Islam: Analisis Fiqih dan Kevangan. Jakarta: PT. RajaGrafindo Persada

Kusmiyati, A. N. S. 2007. Risiko Akad dalam pembiayaan Murabahah pada BMT di Yogyakarta (dari Teori ke Terapan). Yogyakarta. La_Riba Jurnal Ekonomi Islam Vol 1 (1) 27-41

Lubis, Suhrawardi K. Dan Farid Wajdi. 2012. Hukum Ekonomi Islam. Jakarta. Sinar Grafika

Muhamad. 2016. Manajemen Kevangan Syariah Analisis figh 
dan Kevangan.Yogyakarta.

UPP STIM YKPN

Nawawi, Ismail. 2009. Ekonomi

Kelembagaan Syariah: Dalam

Pusaran Ekonomi Global

Sebuah Tuntutan dan

Realitas. Surabaya. CV. Putra

Medika Nusantara.

Rivai, Veithzal dan Andria Permata

Veithzal. 2008. Islamic Financial

Management:Teori, Konsep

dan Aplikasi Panduan Praktis

untuk Lembaga Kevangan,

Nasabah, Praktisi dan

Mahasiswa. Jakarta: Raja

Grafindo Persada

Rivai, Veithzal dan Rifki Ismal. 2013.

Ismalic Risk Management Fot

Islamic Bank. Jakarta:

Gramedia Pustaka Utama.

Romdhoni, A. H. 2016. Analisis Komparasi

Manajemen Risiko pada

Koperasi Syariah di

Kabupaten Boyolali. Surakarta.

Jurnal IImiah Ekonomi Islam Vol.

02 (03) 1-15

Suyanto, Bagong dan Sutinah. 2008.

Metode Penelitian Sosial:

Berbagai Pendekatan Alternatif.

Jakarta. Kencana

Yusuf, Saifullah. 2017. Perubahan

Berkelanjutan: Gotong Royong

Memakmurkan Jawa

Timur. Surabaya. Airlangga

university press.

Yin, R. K. 2009. Studi Kasus: Desain dan Metode. Jakarta. Raja Wali 